\title{
A STUDY ON LANDSLIDE PRONE ZONES IN SAKALESHAPUR TALLUK, WESTERN GHATS, KARNATAKA, INDIA
}

\author{
Aneesah Rahaman ${ }^{1}$ and Madha Suresh. $\mathbf{V}^{2}$ \\ ${ }^{1}$ Research Scholar CNDHS, University of Madras, Chennai, India \\ ${ }^{2}$ Professor and Head, CNHDS, University of Madras, Chennai, India \\ Email: aneesah0786@gmail.com
}

\begin{abstract}
Landslides are the common phenomena in the hilly terrain of Western Ghats region due to the heavy rainfall. The occurrence of landslides in the study area Sakleshpura and Belthanggudi Talluk in Karnataka state is quite less in comparison to Himalayan region. In the year 2018, during monsoon season the study area faced divesting floods and landslides. The aim of this study is to identify the landslide prone zones using Frequency Ratio Model with the help of ArcGIS software. The factors considered for this study are slope, soil, drainage density, distance from drainage and rainfall. All the spatial data have been calculated using frequency ratio model and each grid factor has been summed up into three categories such as high, moderate and low hazard zone. The results of this study reveals that that 160 sq.km areas is under very low with landslide density (LD) of 0.01, $894 \mathrm{~s} . \mathrm{km}$ area is under medium zone with $L D$ of $0.02,75.36$ sq. $\mathrm{km}$ area is under high hazard zone with $L D$ of 0.05 . The study also reveals that the soil is more vulnerable factor for landslide on the basis of frequency ratio value flowed by rainfall, slope, distance from drainage and drainage density in the study area. The final output of the map can be helpful for the local government of the study area.
\end{abstract}

\section{Key words: Landslide, frequency ratio, hazard zone, GIS, Western Ghats.}

\section{Introduction}

Landslide is the downward movement of the earth materials under the impact of gravity. On the basis of various physical factors in the study area such as geological, geo-environmental, geomorphological and hydrological, usually landslide happens under these various conditions (M. Geertsema et al., 2009). There are many natural processes that shape the earth's surface, landslide is one of them. It has been said that landslide took third position in the world as a natural disaster that can leads many damages (Zillman, 2000). It is happened only when the landslide threatens to human beings as a hazard. In hilly mountainous region landslide is the most natural hazards (Rammohan et al., 2011). It is very common that in each year number of people gets damaged and also loses their lives, property in landslides all over the world. The hilly slope may unstable due to the deficiency of proper geotechnical investigation and leads to the adverse effects on the geo-environment in that region (R. Anbalagan et al., 2008). By these phenomena the local and global economy is also affected. Since 25 years or more, many government, local organization and international institute are investing resources to manage and mitigate the landslide hazards with the help of Susceptibility Map throughout the world (Guzzetti et al., 1999). For the study of landslide hazard mapping some temporal factors should be included such as earthquake, rainfall, variation of temperature (Guzzetti et al. 2006; Pradhan et al. 2010; Dahal et al. 2012). To mitigate the landslide hazard, the Landslide Hazard Evaluation Factor (LHEF) rating can be done and this factor is based on the existence of causative factors in the area of study. The similar technique has been applied in the rock mass classification e.g., RMR and the Q system (Barton et al., 1974; Bieniawski, 1979). For susceptibility of landslide mapping in GIS environment, tools and techniques have been classified into two approaches such as subjective and objective and the mapping of invention and analysis of expert are existed in subjective approaches (Lee et al. 1991; Soeters and Van Western 1996; Wang et al. 2009). In case of indirect mapping of susceptibility approaches, many studies have been done through the application of very popular tool such as Geographic Information System (GIS) (Bignell and Snelling, 1977). It is possible to identify the slope failure area as well as vulnerable to slope in the form of maps of landslide susceptibility with the help 
of distribution of previous spatial data of landslides and their related causative factors (Nagarajan et al., 1998; Fernandez et al., 2003).

In the present study area Sakeleshpur Taluk in Hassan District, landslide happened in the year of 2018 due to torrential downpour. Since four days' heavy rainfall of an average of 11.9 $\mathrm{cm}$ had been received by the district. Total 120 landslides have been detected with the help of satellites such as ISRO Resource-sat 2, Worldview 2, spot 7 in Kodagu and Hassan Districts in Karnataka State. Out of the total landslides 25 has occurred in the study area (newindiaexpress.com). Besides heavy rainfall, the clay type soil, steep slope, number of drainages and also land use land cover caused the landslides in the study area. The study area is situated in Sahyadri folded mountain belt which is lithologically prone to landslides. The study area is covered by red gravelly clay type soil in which occurrence of landslides depended. This area has a loose and unconsolidated soil. Weathering is influenced by the climatic condition of the Western Ghats which is also one of the major causes of landslides. Most of the landslide is debris type in the study area. In the year of 2018 the heavy rainfall caused the massive landslides.

\section{Study Area}

Geographically the study area Shekeleshpur Talluk, consists of 221 villages of Hassan District of Karnataka State is located $12.943^{\circ} \mathrm{N} 75.775^{\circ} \mathrm{E}$ with a geographical area of $1,129.68 \mathrm{sq} . \mathrm{km}$. Geomorphologically it is situated in the Sahyadri folded mountain of Western Ghats with an elevation of $956 \mathrm{~m}$ above Mean Sea Level (MSL). The Hemavathy and Kavery is the main river in this region which is empties into the Arabian Sea. Weathering and erosion is very high due to the heavy intensity of rainfall. The average annual rainfall is $2178 \mathrm{~mm}$ and the average annual temperature is 22.7 degree Celsius. According to 2011 census total population of the study area is 23,352 among them the total male population is 11,558 and female population is 11,754 .

\section{Figure 01: Study Area}

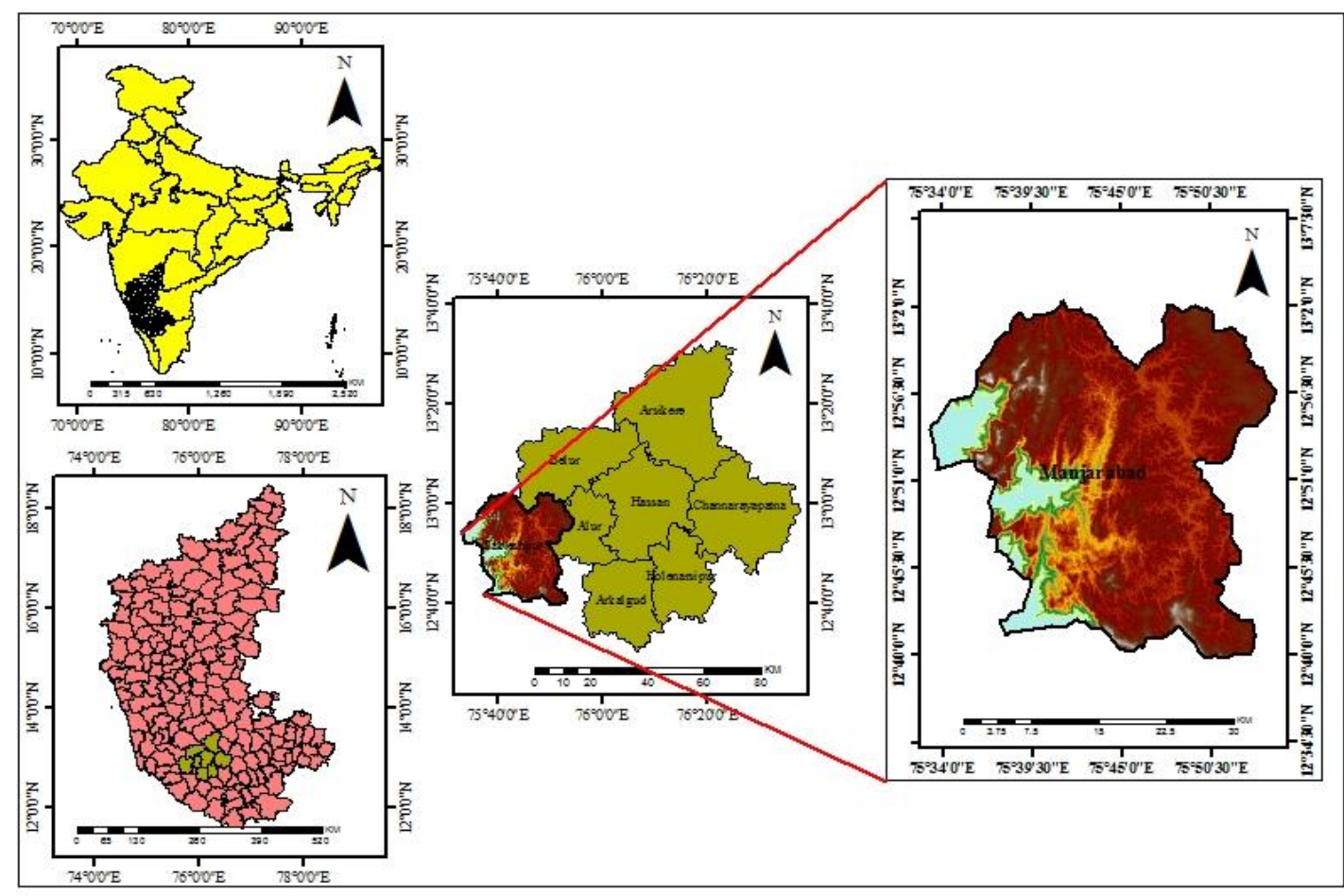

\section{Objective}

- The objective of this study is to identify the root cause of landslide in this region.

- To demarcate the landslides prone zone using Frequency Ratio Model with the help of the ArcGIS software.

Database and Methodology

In this present study five causative factors have been used such as slope, soil, distance from drainage, rainfall and drainage density. Table 1 show the data used of this study. 
Table 01: Data Used in the Present Study

\begin{tabular}{|l|l|l|}
\hline \multicolumn{1}{|c|}{ Data Type } & \multicolumn{1}{c|}{ Source } & \multicolumn{1}{c|}{ Data Derive } \\
\hline Carto DEM (1 m resolution) & Bhuvan, NRSC & $\begin{array}{l}\text { Slope, distance from drainage } \\
\text { and Drainage Density Map }\end{array}$ \\
\hline Soil & Raitamitra.kar.nic.in & Soil Type Map \\
\hline Landslide & $\begin{array}{l}\text { Sentinel 2B and Google } \\
\text { Earth }\end{array}$ & Landslide Inventory Map \\
\hline Rainfall & IMD, Karnataka & Rainfall Distribution Map \\
\hline
\end{tabular}

There are number of bivariate statistical method that can be used to prepare the susceptibility of landslide mapping, among them Frequency Ratio (FR) Model is one and in the present study, FR model has been used (Pradhan and Lee, 2009). The FR model can build the spatial relationship between the location of landslide and the factors of landslides (Lee, 2005). GIS based Frequency Ratio Model has been applied based on the causal relationship between the causative factors and the occurrence of landslide in this area. It has fixed value of 1 . The value more than 1 indicates the higher correlation between the causative factors and the occurrence of landslide. On the other hand, value less than 1 shows the lower correlation. After creating all the thematic layers have been converted into raster and reclassification has also been done using ArcGIS 10.4 software. Occurrence of landslide (LS), percentage of LS occurrence, total number of pixel, percentage of pixel have been identified and frequency ratio have been calculated of each factor such as slope, soil, distance from drainage, drainage density and rainfall of the study area. All the layers have been summed up and finally the landslide hazard prone map has been done with three classes namely high, moderate and low in the study area.

\section{RESULTS AND DISCUSSION}

\section{Relationship between Soil and Landslides}

The type of soil has been classified into four classes including water such as red gravelly clay soil, coastal lateritic soil, and lateritic gravelly soil and water bodies. The maximum number of landslides has occurred in red gravelly clay type soil 13 out of the total landslides 25, followed by coastal laterite, lateritic gravelly and water bodies. Figure 3 shows the soil map of the study area. Table 1 describes that the frequency ratio of each soil types. In this table the soil type red gravelly clay shows the maximum number of landslides of 13 out of total landslides 25 which is 52 percentages. The frequency ratio of the soil class has been calculated with the percentage of landslide occurrence divided by the percentage of pixel domain which is 5.78. Likewise, frequency ratio of all the other soil type has been calculated.

Table 01: Frequency Ratio of Soil to Landslide occurrences

\begin{tabular}{|l|c|c|c|c|c|c|}
\hline Soil class & $\begin{array}{l}\text { No. of } \\
\text { Pixels }\end{array}$ & $\begin{array}{l}\text { Landslide } \\
\text { occurrence }\end{array}$ & $\begin{array}{l}\text { Landslide } \\
\text { occurrence \% }\end{array}$ & $\begin{array}{l}\text { Pixels } \\
\text { domain }\end{array}$ & $\begin{array}{l}\text { Pixels } \\
\text { domain \% }\end{array}$ & Ratio \\
\hline $\begin{array}{l}\text { Red Gravelly Clay } \\
\text { Soil }\end{array}$ & 3914 & 13 & 52 & 3914 & 8.99 & 5.78 \\
\hline $\begin{array}{l}\text { Coastal Laterite } \\
\text { Soil }\end{array}$ & 18488 & 8 & 32 & 18488 & 42.49 & 0.75 \\
\hline $\begin{array}{l}\text { Lateritic Gravelly } \\
\text { Soil }\end{array}$ & 15501 & 2 & 8 & 15501 & 35.62 & 0.22 \\
\hline Waterbodies & 5610 & 2 & 8 & 5610 & 12.89 & 0.62 \\
\hline Total & $\mathbf{4 3 5 1 3}$ & $\mathbf{2 5}$ & $\mathbf{1 0 0}$ & $\mathbf{4 3 5 1 3}$ & $\mathbf{1 0 0}$ & $\mathbf{7 . 3 8}$ \\
\hline
\end{tabular}

\section{Relationship between Rainfall and landslides}

The average rainfall has been classified into five classes as $1761 \mathrm{~mm}, 1833 \mathrm{~mm}, 1904 \mathrm{~mm}$, $1976 \mathrm{~mm}$ and $2047 \mathrm{~mm}$. The maximum number of landslides has occurred in $1976 \mathrm{~mm}$ average rainfall class of 17 out of the total landslides 25, followed by 1904, 1833 and $1761 \mathrm{~mm}$. Figure 4 shows the rainfall map of the study area. Table 2 explains the frequency ratio of each average of rainfall classes. In this table the maximum number of landslides has occurred in $1904 \mathrm{~mm}$ rainfall class are 11 out of total landslides 25 which are 68 percentages. The frequency ratio of this class has been calculated with the percentage of landslide occurrence divided by the percentage of pixel domain which is 3.13. Likewise, frequency ratio of all the other rainfall class has been calculated. 
Table 02: Frequency Ratio of Rainfall to Landslide occurrences

\begin{tabular}{|c|c|c|c|c|c|c|}
\hline $\begin{array}{c}\text { Rainfall } \\
\text { (mm) }\end{array}$ & $\begin{array}{c}\text { No. of } \\
\text { Pixels }\end{array}$ & $\begin{array}{c}\text { Landslide } \\
\text { occurrence }\end{array}$ & $\begin{array}{c}\text { Landslide } \\
\text { occurrence \% }\end{array}$ & $\begin{array}{c}\text { Pixels } \\
\text { domain }\end{array}$ & $\begin{array}{c}\text { Pixels } \\
\text { domain \% }\end{array}$ & Ratio \\
\hline 1761 & 13913 & 0 & 0 & 13913 & 32.52 & 0 \\
\hline 1833 & 8169 & 1 & 4 & 8169 & 19.09 & 0.21 \\
\hline 1904 & 5525 & 7 & 28 & 5525 & 12.91 & 2.17 \\
\hline 1976 & 9281 & 17 & 68 & 9281 & 21.69 & 3.13 \\
\hline 2047 & 5892 & 0 & 0 & 5892 & 13.77 & 0 \\
\hline Total & $\mathbf{4 2 7 8 0}$ & $\mathbf{2 5}$ & $\mathbf{1 0 0}$ & $\mathbf{4 2 7 8 0}$ & $\mathbf{1 0 0}$ & $\mathbf{5 . 5 1}$ \\
\hline
\end{tabular}

Relationship between Distance from drainage and Landslides

The distance from drainage to landslide has been classified into six classes such as $250 \mathrm{~m}$, $500 \mathrm{~m}, 750 \mathrm{~m}, 1000 \mathrm{~m}, 1250 \mathrm{~m}$ and $1500 \mathrm{~m}$ by using buffer tools. The maximum number of landslides has occurred in $250 \mathrm{~m}$, followed by $500 \mathrm{~m}, 750 \mathrm{~m}, 1000 \mathrm{~m}, 1500 \mathrm{~m}$ and $1250 \mathrm{~m}$. Figure 5 shows the drainage distance from landslide map of the study area. Table 3 shows that the frequency ratio of each drainage buffer categories. In this table the drainage class of $250 \mathrm{~m}$ shows the maximum number of landslides of 9 out of total landslides 25 which is 34.62 percentages. The frequency ratio of the buffer class has been calculated with the percentage of landslide occurrence divided by the percentage of pixel domain which is 0.97. Likewise, frequency ratio of all the other buffer classes has been calculated.

Table 03: Frequency Ratio of Distance from Drainage to Landslide occurrences

\begin{tabular}{|c|c|c|c|c|c|c|}
\hline $\begin{array}{c}\text { Distance from } \\
\text { drainage }(\mathbf{m})\end{array}$ & $\begin{array}{c}\text { No. of } \\
\text { Pixels }\end{array}$ & $\begin{array}{c}\text { Landslide } \\
\text { occurrence }\end{array}$ & $\begin{array}{c}\text { Landslide } \\
\text { occurrence \% }\end{array}$ & $\begin{array}{c}\text { Pixels } \\
\text { domain }\end{array}$ & $\begin{array}{c}\text { Pixels } \\
\text { domain \% }\end{array}$ & Ratio \\
\hline 250 & 15876 & 9 & 34.62 & 15876 & 35.69 & 0.97 \\
\hline 500 & 13377 & 8 & 30.77 & 13377 & 30.07 & 1.02 \\
\hline 750 & 8588 & 5 & 23.08 & 8588 & 19.30 & 1.19 \\
\hline 1000 & 3136 & 2 & 7.69 & 3136 & 7.05 & 1.09 \\
\hline 1250 & 1813 & 0 & 0 & 1813 & 4.08 & 0 \\
\hline 1500 & 1699 & 1 & 3.85 & 1699 & 3.82 & 1.00 \\
\hline Total & $\mathbf{4 4 4 8 9}$ & $\mathbf{2 5}$ & $\mathbf{1 0 0}$ & $\mathbf{4 4 4 8 9}$ & $\mathbf{1 0 0}$ & $\mathbf{5 . 2 9}$ \\
\hline
\end{tabular}

\section{Relationship between Slope and Landslides}

Slope has been classified into five categories such as, $0-7^{\circ}, 7^{\circ}-12^{\circ}, 12^{\circ}-20^{\circ}, 20^{\circ}-30^{\circ}$, $>30^{\circ}$. The maximum number of landslide has occurred in the slope category of $20^{\circ}-30^{\circ}$, followed by $>30^{\circ}, 7^{\circ}-12^{\circ}, 12^{\circ}-20^{\circ}$, and $0^{\circ}-7^{\circ}$. Figure 6 shows the slope map of the study area.

Table 04: Frequency Ratio of Slope to Landslide occurrences

\begin{tabular}{|c|c|c|c|c|c|c|}
\hline $\begin{array}{c}\text { Slope } \\
\text { class }\end{array}$ & $\begin{array}{c}\text { No. of } \\
\text { Pixels }\end{array}$ & $\begin{array}{c}\text { Landslide } \\
\text { occurrence }\end{array}$ & $\begin{array}{c}\text { Landslide } \\
\text { occurrence \% }\end{array}$ & $\begin{array}{c}\text { Pixels } \\
\text { domain }\end{array}$ & $\begin{array}{c}\text { Pixels } \\
\text { domain \% }\end{array}$ & Ratio \\
\hline $0--7$ & 284034 & 2 & 7.69 & 284034 & 28.41 & 0.27 \\
\hline $7--12$ & 331028 & 5 & 19.23 & 331028 & 33.11 & 0.58 \\
\hline $12--20$ & 229106 & 4 & 19.23 & 229106 & 22.92 & 0.84 \\
\hline $20--30$ & 114667 & 8 & 30.77 & 114667 & 11.47 & 2.68 \\
\hline $30--60$ & 40804 & 6 & 23.08 & 40804 & 4.08 & 0.00 \\
\hline Total & $\mathbf{9 9 9 6 3 9}$ & $\mathbf{2 5}$ & $\mathbf{1 0 0}$ & $\mathbf{9 9 9 6 3 9}$ & $\mathbf{1 0 0}$ & $\mathbf{4 . 4 3}$ \\
\hline
\end{tabular}

Table 1 shows the frequency ratio of each slope category. In this table the slope category of $20^{\circ}-30^{\circ}$ shows the maximum number of landslides of 8 out of total landslides 25 which is 30.77 percentage. The frequency ratio of the slope has been calculated with the percentage of landslide occurrence divided by the percentage of pixel domain which is 2.68 . Likewise, frequency ratio of all the other slope classes has been calculated.

\section{Relationship between Drainage Density and Landslides}

The density of drainage has been classified into five classes as $0-1.2,1.3-2.3,2.4-3.5,3.6-4.6$ and 4.7-5.8. The maximum number of landslides has occurred in 1.3-2.3 of 11 out of the total landslides 25, followed by $0-1.2,2.4-3.5,3.6-4.6$ and 4.7-5.8. Figure 7 shows the drainage density map of the study area. Table 4 shows that the frequency ratio of each drainage density classes. In this table the class interval 1.3-2.3 shows the maximum number of landslides of 11 
out of total landslides 25 which is 44 percentages. The frequency ratio of the density class has been calculated with the percentage of landslide occurrence divided by the percentage of pixel domain which is 1.16 . Likewise, frequency ratio of all the other drainage density has been calculated.

Table 05: Frequency Ratio of Drainage Density to Landslide occurrences

\begin{tabular}{|c|c|c|c|c|c|c|}
\hline $\begin{array}{c}\text { Drainage } \\
\text { density }\end{array}$ & $\begin{array}{c}\text { No. of } \\
\text { Pixels }\end{array}$ & $\begin{array}{c}\text { Landslide } \\
\text { occurrence }\end{array}$ & $\begin{array}{c}\text { Landslide } \\
\text { occurrence \% }\end{array}$ & $\begin{array}{c}\text { Pixels } \\
\text { domain }\end{array}$ & $\begin{array}{c}\text { Pixels } \\
\text { domain \% }\end{array}$ & Ratio \\
\hline $0-1.2$ & 17631 & 8 & 32 & 17631 & 41.18 & 0.78 \\
\hline $1.3-2.3$ & 16201 & 11 & 44 & 16201 & 37.84 & 1.16 \\
\hline $2.4-3.5$ & 7014 & 5 & 20 & 7014 & 16.38 & 1.22 \\
\hline $3.6-4.6$ & 1821 & 1 & 4 & 1821 & 4.25 & 0.94 \\
\hline $4.7-5.8$ & 145 & 0 & 0 & 145 & 0.34 & 0 \\
\hline Total & $\mathbf{4 2 8 1 2}$ & $\mathbf{2 5}$ & $\mathbf{1 0 0}$ & $\mathbf{4 2 8 1 2}$ & $\mathbf{1 0 0}$ & $\mathbf{4 . 1 0}$ \\
\hline
\end{tabular}

\section{Reclassification using Frequency Ratios}

In the present study five parameters have been taken as a causative factor for the preparation of landslide hazard map have been assigned the method of Frequency Ratio by using ArcGIS software 10.4. For the preparation final map, all the thematic maps have been reclassified by using ArcGIS Spatial Analyst extension tool. All the reclassified maps have been shown in figure wise.

\section{Landslide Susceptibility Mapping (LSM)}

In this study, the GIS based Frequency Ratio has been applied to prepare the Landslide Susceptibility Map by using five causative factors such as slope, drainage density, and distance to drainage, rainfall and soil. To calculate the Landslide Susceptibility Index (LSI) all the parameters has been converted into $30 * 30 \mathrm{~m}$ grid cells. The total number of cell is 42290 and the total number of landslide is 25 in the study area. In the overlay analysis tool, the summation of each frequency ratio value has been given to calculate the LSI.

$\mathrm{LSI}=\Sigma \mathrm{Fr}$ (where $\mathrm{Fr}$ is the frequency ratio of each causative factors)

The landslide hazard zonation (LHZ) map has been created by using LSI assigned value to each cell. According to frequency ratio table, the frequency ratio of soil is maximum of 7.38 , followed by rainfall is 5.51 , distance to drainage is 5.29 , slope is 4.43 and drainage density is 4.1. Therefore, all the frequency value has been multiplied by 100 and has been put on the weighted overlay table according to their highest to lowest weight by using ArcGIS software. The final LHZ map has been presented in figure 8.

\section{Validation}

The final LHZ map of the study area should be validated in respect to each causative factor with landslide inventory map to check the prediction is matched with the expected outcome or not. All the parameters such as slope, soil, rainfall, drainage density and distance to drainage maps have been considered with landslide and overlaid on the LHZ map and also the distribution of landslide in each zone has been calculated which is shown in figure 8.

Table 06: Landslides, Area and Landslide Density in the LSM (Landslide Susceptibility)

\begin{tabular}{|c|c|c|c|c|c|c|}
\hline LS Classes & LS & LS \% & Pixel Domain & Pixel \% & Area(sq.km) (A) & LS/A \\
\hline Low & 1 & 4 & 5337 & 14.17 & 160.11 & 0.01 \\
\hline Medium & 20 & 80 & 29807 & 79.15 & 894.21 & 0.02 \\
\hline High & 4 & 16 & 2512 & 6.67 & 75.36 & 0.05 \\
\hline Total & $\mathbf{2 5}$ & $\mathbf{1 0 0}$ & $\mathbf{3 7 6 5 6}$ & $\mathbf{1 0 0}$ & $\mathbf{1 1 2 9 . 6 8}$ & $\mathbf{0 . 0 8}$ \\
\hline
\end{tabular}

The LHZ map has been classified into three zone such as Low, Medium and High hazard zone by using Jenks method of natural break in ArcGIS software. The LHZ map shows that the maximum number of landslide has occurred in medium zone are 20 and 4 in high zone and 1 in low zone. Out of the total area of 1129.68 sq.km, medium hazard zone covered $894.21 \mathrm{sq} . \mathrm{km}$ areas, high zone is $75.36 \mathrm{s.km}$ and low zone covered $160.11 \mathrm{s.km}$ areas. Therefore, the results of the present study reveal that the study area is fall under medium to high hazard zone (table $6)$. 


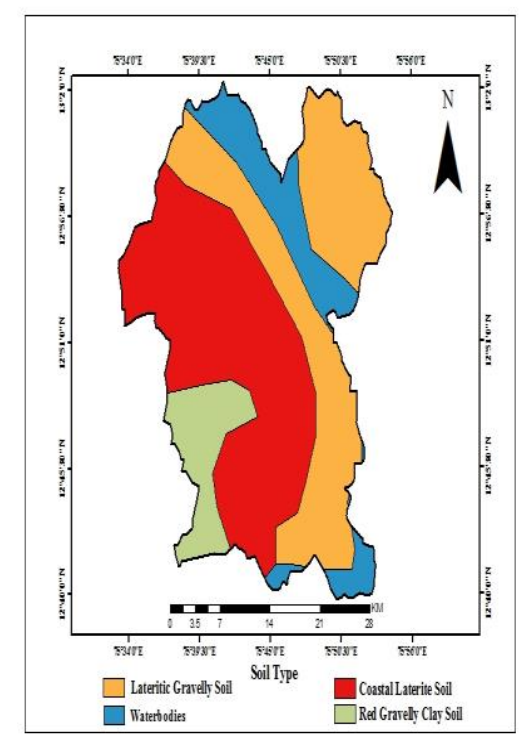

Figure 3: Soil

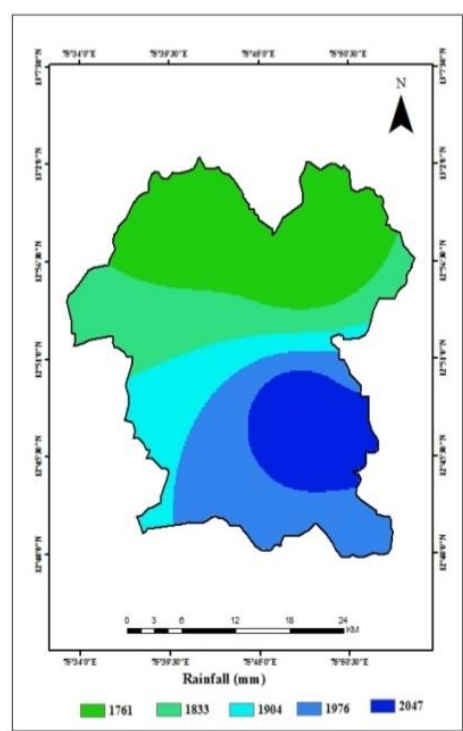

Figure 4: Rainfall

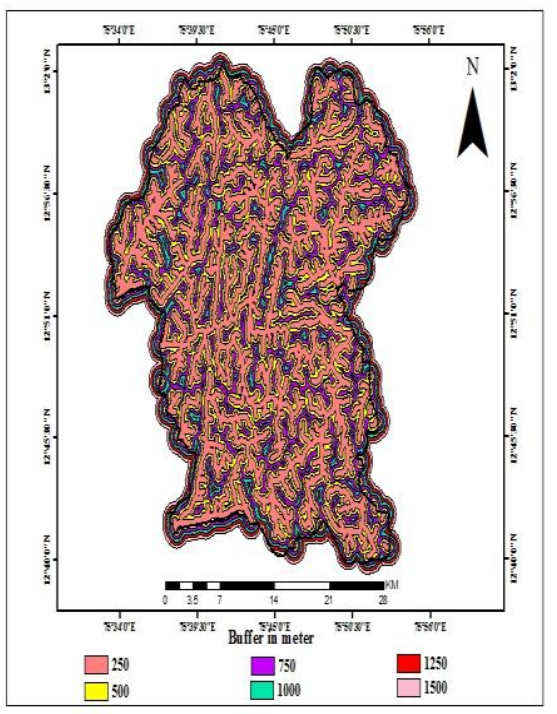

Figure 5: Drainage Buffer

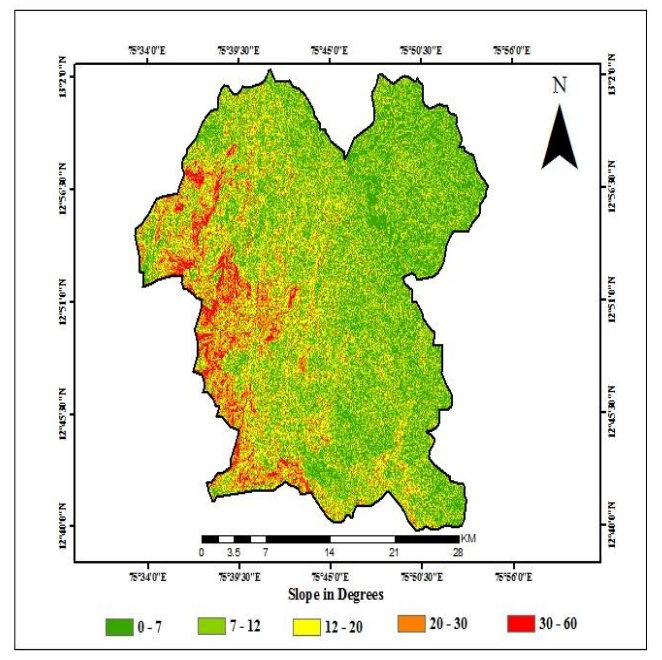

Figure 7: Drainage Density

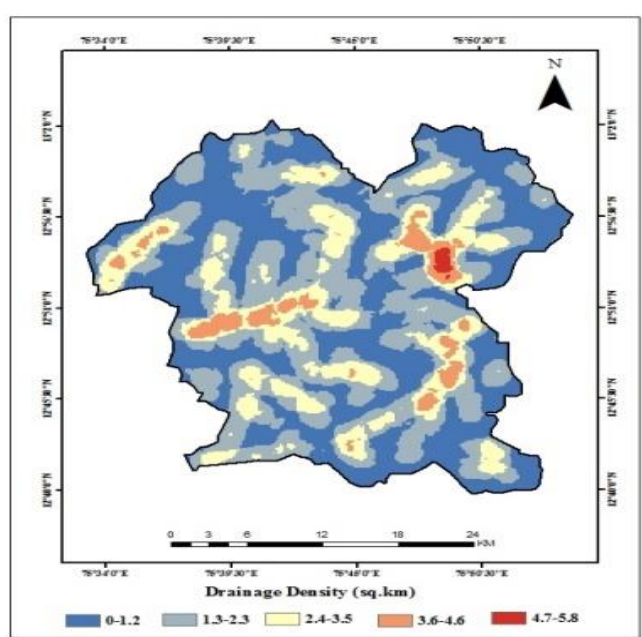

Figure 6: Slope

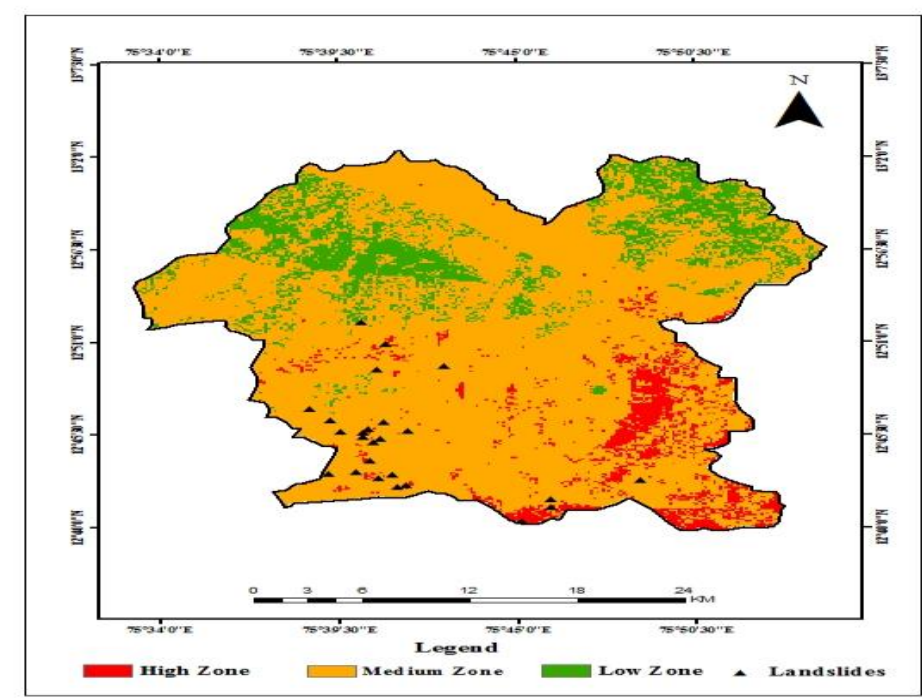

Figure 8: Landslide Hazard Zonation Map 


\section{Conclusion}

The landslide hazard zonation (LHZ) mapping based on the Frequency Ratio technique has given the acceptable results. The study also reveals that the soil is more vulnerable factor for landslide on the basis of frequency ratio value flowed by rainfall, slope, distance from drainage and drainage density in the study area. Beside this hilly terrain with steep slope and the heavy rainfall in 2018 also leads the major role on the landslides.

\section{References}

1. Anbalagan $R$ (1992) "Landslide hazard evaluation and zonation mapping in mountainous terrain”, Eng. Geol. Vol. 32 pp: 269-277.

2. Anbalagan R, Chakraborty D and Kohli A (2008) "Landslide hazard zonation (LHZ) mapping on meso-scale for systematic town planning in mountainous terrain", J. Sci. Indus. Res, Vol. 67, pp: 486-497.

3. Anbalagan. Rathinam, Kumar. Rohan, Parida. Sujata and Neethu. Sasidharan (2015) "Landslide hazard zonation mapping using frequency ratio and fuzzy logic approach, a case study of Lachung Valley, Sikkim, Anbalagan et al. Geo-environmental Disasters, Vol.2.

4. Dong. Wei, Jing. Wang, Li. Guo, Fang. Gang and Sheng Chang. Xin (2012) "A subjective and objective integrated weighting method for landslides susceptibility mapping based on GIS", Environmental Earth Sciences, Vol.65, Issue 6, pp: 1705-1714.

5. F. Laila, P.T Binh, Solanki. A.H, Pazhman. Dalat, Dholakia. B.M and Khalid.M (2018) "Application of Frequency Ratio Model for the Development of Landslide Susceptibility Mapping at Part of Uttarakhand State, India", International Journal of Applied Engineering Research, Vol.13.

6. Geographical Information Systems in Assessing Natural hazards (eds) Carrara A and Guzzetti F (Dordrecht, The Netherlands: Kluwer Academic Publishers), pp. 135-175.

7. Javad. Mirnazari, Baharin. Ahmad, Barat and Sttari. Farshad (2014) "Using Frequency Ratio Method for Spatial Landslide Prediction", Research Journal of Applied Sciences, Engineering and Technology, Vol.7, pp: 3174-3180.

8. N. Intarawichian and S. Dasananda (2011) "Frequency ratio model based landslide susceptibility mapping in lower Mae Chaem watershed, Northern Thailand", Environ Earth Sci, Vol. 64, pp: 2271-2285.

9. Pardeshi. Sudhakar D, Autade. Sumant E and Pardeshi. Suchitra. S (2013) "Landslide hazard assessment: recent trends and techniques Landslide hazard assessment: recent trends and techniques", Pardeshi et al. Springer Plus, Vol.2, pp:523.

10. Regmi D A, Devkota. C.K, Yoshida. Kohki and Biswajeet. Pradhan (2013) "Application of frequency ratio, statistical index, and weights-of-evidence models and their comparison in landslide susceptibility mapping in Central Nepal Himalaya, Arab J Geosci.

11. Roslee. Rodeano, Clancey. Alvyn, Simon. Norbert and Norhisham. Norazman. Mohd (2017) "Landslide Susceptibility Analysis (Lsa) Using Weighted Overlay Method (Wom) Along the Genting Sempah to Bentong Highway, Pahang", Malaysian Journal Geosciences (MJG), Vol. 1(2), pp:13-19.

12. V.Mohan. Ram, T. Raj. Naveen, T.Narmatha and M. Jayaprakash (2011) "Landslide susceptibility mapping using frequency ratio method and GIS in south eastern part of Nilgiri District, Tamilnadu, India", International Journal of Geomatics and Geosciences, Vol. 1. 